\title{
DAMPAK PERCERAIAN YANG TIDAK SESUAI DENGAN PROSEDUR PERUNDANG-UNDANGAN
}

\author{
Ramadhan Syahmedi Siregar \\ Lecturer of Syariah and Law Sciences Faculty at UIN North Sumatera \\ Jl. Williem Iskandar Pasar V, Medan Estate, Medan, Sumatera Utara 20371 \\ Email: ramedin975@gmail.com
}

\begin{abstract}
Divorce is a legal event, and then it should be an event carried out in accordance with rules of legal and judicial procedures. Otherwise it will result in lack recognized a divorce, this is in line with what is mandated in Law No. 1 of 1974 on article 38 and 39, which reads: "Divorce can only be done in front of the competent court after the relevant court and unsuccessfully tried to reconcile the two parties", it is stated in article 38 of Law No. 1 of 1974. While the Article 39 paragraph (2) to conduct a divorce there must be a sufficient reason that between husband and wife will not be able to live in harmony as husband and wife.
\end{abstract}

Keywords: Impact, Divorce Law, Procedure

\begin{abstract}
Abstrak
Perceraian adalah peristiwa hukum, dan kemudian harus menjadi acara dilakukan sesuai dengan aturan prosedur hukum dan peradilan. Jika tidak, akan mengakibatkan kurangnya diakui secara perceraian, hal ini sejalan dengan apa yang diamanatkan dalam Undang-Undang Nomor 1 Tahun 1974 tentang artikel 38 dan 39, yang berbunyi: "Perceraian hanya dapat dilakukan di depan pengadilan yang berwenang setelah pengadilan yang relevan dan gagal mencoba untuk mendamaikan kedua belah pihak ", dinyatakan dalam pasal 38 Undang-undang Nomor 1 tahun 1974. Sedangkan Pasal 39 ayat (2) untuk melakukan perceraian harus ada cukup alasan bahwa antara suami dan istri tidak akan mampu hidup secara harmonis sebagai suami dan istriami dan istri tidak akan mampu hidup secara harmonis sebagai suami dan istri.
\end{abstract}

Kata Kunci: Dampak, Perceraian, UU, Prosedur.

\section{PENDAHULUAN}

Indonesia yang berdasarkan atas hukum, ada beberapa produk hukum yang mengatur masalah perkawinan. Tetapi dengan berlakunya Undang-Undang Nomor 1 Tahun 1974 tentang Perkawinan dan Peraturan Pemerintah Nomor 9 Tahun 1975 sebagai Peraturan Pelaksanaannya, maka terdapat unifikasi dibidang Hukum Perkawinan bagi seluruh Warga Negara Indonesia tanpa melihat agama, suku maupun golongan masing-masing. Hal ini dengan tegas telah disebut dalam Pasal 66 Undang-Undang Perkawinan yang menentukan bahwa berlakunya Undang-Undang ini maka ketentuan yang diatur dalam Kitab UndangUndang Hukum Perdata (Burgerlijk Wetboek), Ordonansi Perkawinan Indonesia Kristen (Huwelijks Ordonantie Cristen Indonesia Staatblat 1993 Nomor 74). Peraturan Perkawinan Campuran (Regeling of de Gemengde Huwelijken Staatsblat 1989 Nomor 158) dan Peraturan lain 
yang mengatur tentang Perkawinan sejauh telah diatur undang-undang ini, dinyatakan tidak berlaku.

Di dalam Undang-Undang Perkawinan Nomor 1 Tahun 1974 Pasal 2 ayat (1) tersebut telah dinyatakan secara tegas bahwa syarat sahnya suatu perkawinan harus berdasarkan atas agama dan kepercayaan yang dianut oleh para pihak yang akan melangsungkan perkawinan, dengan demikian bagi Warga Negara Indonesia yang beragama Islam yang hendak melakukan perkawinan supaya sah perkawinannya harus dilaksanakan menurut kentuan hukum perkawinan Islam.

Salah salah satu unsur yang diatur dalam hukum perkawinan adalah yang berkenaan dengan masalah perceraian. Percerian juga harus mengacu pada aturan perundang undangan yang ada yaitu UU Perkawinan pada pasal 38 dan 39 yang berbunyi: : "Perceraian hanya dapat dilakukan di depan sidang pengadilan yang berwenang setelah pengadilan yang bersangkutan berusaha dan tidak berhasil mendamaikan kedua belah pihak" hal ini disebutkan pada pasal 38 UU No.1 tahun 1974. Sementara pada Pasal 39 ayat (2) untuk melakukan perceraian harus ada cukup alasan, bahwa antara suami-isteri itu tidak akan dapat hidup rukun sebagai suami-isteri.

\section{PENGERTIAN PERCERAIAN}

Kata cerai menurut Kamus Besar Bahasa Indinesia adalah: Pisah, putus hubungan sebagai suami istri. Kemudian, kata "perceraian" mengandung arti: Perisahan, perihal bercerai; perpecahan. Adapun kata bercerai bererti: tidak bercampur (berhubungan, bersatu) lagi, berhenti berlaki-bini (suami istri). ${ }^{1}$

Istilah perceraian menurut UU No. 1 tahun 1974 sebagai aturan hukum positif tentang perceraian menunjukkan adanya:

a. Tindakan hukum yang dapat dilakukan oleh suami atau istri untuk memutuskan hubungan perkawinan di antara mereka;

b. Peristiwa hukum yang memutuskan hubungan suami dan istri, yaitu kematian suami atau istri yang bersangkutan, yang merupakan ketentuan yang pasti dan langsung ditetapkan oleh Tuhan yang Maha Kuasa;

c. Putusan hukum yang dinyatakan oleh pengadilan yang berakibat hokum putusnya hubungan perkawinan antara suami dan istri. ${ }^{2}$

Jadi istilah perceraian secara yuridis berarti putusnya perkawinan yang mengakibatkan pututusnya hubungan sebagai suami istri. ${ }^{3}$ Atau sebagaimana yang

\footnotetext{
${ }^{1}$ Tim Penyusun Kamus Pusat Pembinaan dan Pengembangan Bahasa, Kamus Besar Bahasa Indonesia Edisi Kedua (Jakarta: Balai Pustaka, 1997), hlm. 185.

2 Muhammad Syaifuddin, Sri Turatmiyah dan Annalisa Yahana, Hukum Perceraian (Jakarta Timur: Sinar Grafika, 2013), hlm. 16.

${ }^{3} \mathrm{Ibid}$.
} 
diartikan dalam Kamus Besar Bahasa Indonesia di atas adalah berhenti berlaki bini (suami istri). Subekti memberikan pengertian perceraian adalah: "Penghapusan perkawinan dengan putusan hakim, atau tuntutan salah satu pihak dalam perkawinan itu". ${ }^{4}$

Talak berasal dari bahasa Arab yaitu kata اطلاق artinya lepasnya suatu ikatan perkawinan dan berakhirnya hubungan perkawinan. ${ }^{5}$ Sayyid Sabiq memberikan pengertian talak itu secara bahasa adalah, melepaskan atau meninggalkan, talak berasal dari kata itlaq. Sementara dalam pengertian istilah adalah melepaskan ikatan perkawinan atau bubarnya hubungan perkawinan. ${ }^{6}$ Semantara al-Jaziri mendifinisikan bahwa talak itu melepaskan ikatan atau pelepasan ikatan dengan menggunakan kata-kata tertentu. ${ }^{7}$ Menurut Istilah talak adalah:

$$
\text { حل رابطة الزواج واهاء العلاقة الزوجية }
$$

Melepaskan tali perkawinan dan mengakhiri hubungan suami istri. ${ }^{8}$

Sedangkan pengertian talak menurut istilah dalam karya Mahmud Yunus adalah: "Talak itu ialah menghilangkan ikatan pernikahan atau mengurangi pelepasan ikatan dengan menggunakan kata-kata tertentu". 9 Selanjutnya dalam kitab Kifayah al-Akhyar disebutkan: “Talak menurut syara' ialah nama untuk melepaskan tali ikatan nikah dan talak itu adalah lafaz jahiliyah yang setelah Islam datang menetapkan lafaz itu sebagai kata melepaskan nikah. Dalil-dalil tentang talak adalah berdasarkan Al-Kitab As-Sunnah, dan Ijma' ahli agama dan ahlus sunnah". ${ }^{10}$

Al-Jaziri mendefinisikan talak adalah:

الطلاق ازالة النكح اونقصان حله بلفظ مخصوص.11

Talak ialah menghilangkan ikatan perkawinan atau mengurangi pelepasan ikatannnya dengan menggunakan kata-kata tertentu.

Menurut zakaria al-Anshari adalah:

$$
\text { حل عقد النكاح بلفظ الطلاق ونخوه.12 }
$$

Melepas tali akad nikah dengan kata talak dan semacamnya.

Abdul Djamali dalam bukunya, Hukum Islam, mengatakan bahwa perceraian merupakan putusnya perkawinan antara suami-istri dalam hubungan keluarga. Dari definisi yang telah penulis kemukakan di atas, maka dapat penulis simpulkan bahwa yang

4 Subekti, Pokok-Pokok Hukum Perdata (Jakarta: PT. Intermasa), cet. 24, hlm. 42.

${ }^{5}$ H.S.A. Al-Hamdani, Risalah Nikah (Jakarta: Pustaka Amani, 2002), hlm. 202.

${ }^{6}$ Sayyid Sabiq, Fiqh al-Sunnah (Bandung: PT. Al-Ma`arif, 1994), hlm. 9.

${ }^{7}$ Abdurrahman al-jaziri, Kitab al-Figh `ala Mazahib al-Arba`ah, Juz IV (Kairo: Dar al-Fikr, t.t.), hlm. 278.

${ }^{8}$ Abdul Rahman Ghozali, Figh Munakahat (Jakarta: Prenada Media,2003), hlm. 191-192.

9 H. Mahmud Yunus, Kamus Ara Indonesia, Yayasan Penyelenggara Penterjemah/Penafsiran Al-Qur'an (Jakarta, 1973), hlm. 239

10 Imam Taqi al-Din Abu Bakr ibn Muhammad Al-Hussaini, Kifayah Al Akhyar (Beirut: Dar al-Kutub alIlmiah, tth), hlm. 84 .

${ }^{11}$ Abdurrahman al-Jaziriy, al-Figh `ala Madzahib al-Arba`ah (Mesir: Dar al-Irsyad, t.t.), juz. 4, hlm. 94.

${ }^{12}$ Abu Yahya Zakariya al-Anshary, Fath al-Wahhab (Singapura: Sulaiman Mar`iy, t.t,), juz 2, hlm. 72. 
dimaksud talak adalah: Melepas adanya tali perkawinan antara suami isteri dengan mengunakan kata khusus yaitu kata talak atau semacamnya sehingga isteri tidak halal baginya setelah ditalak. ${ }^{13}$

Berakhirnya perkawinan dalam keadaan suami dan isteri masih hidup (perceraian) dapat terjadi atas kehendak suami, dapat terjadi atas kehendak isteri dan terjadi di luar kehendak suami isteri. Menurut hukum Islam, berakhirnya perkawinan atas inisiatif atau oleh sebab kehendak suami dapat terjadi melalui apa yang disebut talak, dapat terjadi melalui apa yang disebut dengan ila' dan dapat pula terjadi melalui apa yang disebut dengan li'an, serta dapat terjadi melalui apa yang disebut zihar.

Berakhirnya perkawinan atas inisiatif atau oleh sebab kehendak isteri dapat terjadi melalui apa yang disebut khiyar aib, dapat terjadi melalui apa yang disebut khulu' dan dapat terjadi melalui apa yang disebut dengan rafa'14 (pengaduan).

Berakhirnya perkawinan di luar kehendak suami dapat terjadi atas inisiatif atau oleh sebab kehendak hakam, dapat terjadi oleh sebab kehendak hukum dan dapat pula terjadi oleh sebab matinya suami atau isteri. Sejalan dengan keterangan di atas, Fuad Said mengemukakan bahwa perceraian dapat terjadi dengan cara: talak, khulu, fasakh, li'an dan ila' ${ }^{\prime 5}$ Oleh sebab itu menurut Mahmud Yunus bahwa Islam telah memberikan hak talak kepada suami untuk menceraikan isterinya dan hak khulu' kepada isteri untuk menceraikan suaminya dan hak fasakh untuk kedua suami-isteri.

Dalam Kompilasi Hukum Islam pada pasal 113, disebutkan bahwa perkawinan dapat putus karena:

1. Kematian

2. Perceraian

3. Putusan Pengadilan

Pada pasal 11 dijelaskan bahwa: "Putusnya perkawinan yang disebabkan karena perceraian dapat terjadi karena talak atau berdasarkan gugatan perceraian. Selanjytnya pada pasal 115 bahwa: Perceraian hanya dapat dilakukan di depan sidang Pengadilan Agama setelah Pengadilan Agama tersebut berusaha dan tidak berhasil mendamaikan kedua belah pihak.

Sementara pengertian perceraian dalam istilah tradisi hukum adat adalah: "peristiwa luar biasa, merupakan problema sosial dan yuridis yang penting dalam kebanyakan daerah. ${ }^{16}$ Dikatakan peristiwa luar biasa disebabkan prilaku perceraian dalam tradisi hukum

\footnotetext{
${ }^{13}$ Abdul Djamali, Hukum Islam (Bandung: Mandar Maju, 1997), hlm. 95.

14 Zahry Hamid, Pokok-Pokok Hukum Perkawinan Islam dan Undang-Undang Perkawinan di Indonesia (Yogyakarta: Bina Cipta, 1978), hlm. 73.

${ }^{15}$ Fuad Said, Perceraian Menurut Hukum Islam, (Jakarta: Pustaka al-Husna, 1994), hlm. 2. Ila` sumpah suami yang mampu melakukan hubungan badan untuk tidak menggauli istrinya selamanya atau dengan tempo waktu lebih dari empat bulan.

${ }^{16}$ Soerojo Wignjodipoero, Pengantar dan Asas-Asas Hukum Adat (Jakarta: Haji Masagung, 2004), hlm. 143.
} 
adat merupakan hal yang tidak disukai, cita-cita orang Jawa ialah perjodohan sekali untuk seumur hidup, bilamana mungkin sampai kakek nenek pasangan tersebut rukun hingga tua renta sampai bercucu dan bercicit. ${ }^{17}$

\section{DASAR HUKUM PERCERAIAN}

Permasalahan perceraian atau talaq dalam hukum Islam dibolehkan dan diatur dalam dua sumber hukum Islam, yakni Alquran dan hadis Nabi. Hal ini dapat dilihat pada sumber-sumber dasar hukum berikut ini, dalam surat al- Baqarah ayat 231 disebutkan bahwa:

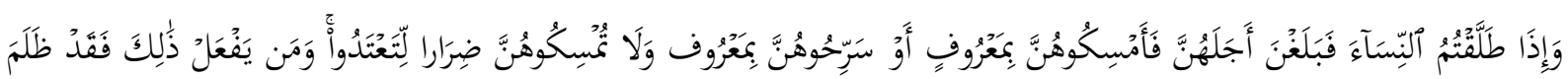

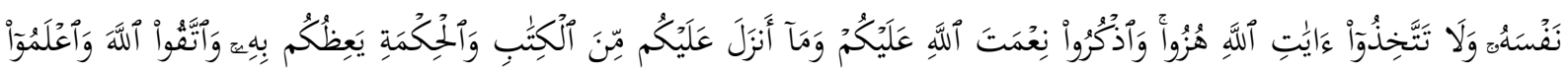

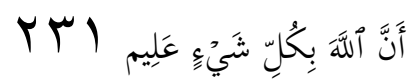

Artinya: "Apabila kamu mentalak istri-istrimu, lalu mereka mendekati akhir iddahnya, maka rujukilah mereka dengan cara yang ma'ruf atau ceraikanlah mereka dengan cara ma'ruf (pula). Janganlah kamu rujuki mereka (hanya) unuk memberi kemudlaratan, karena dengan demikian kamu menganiaya mereka. Barang siapa takut berbuat zalim pada dirinya sendiri, janganlah kamu jadikan hukum Allah suatu permainan dan ingatlah nikmat Allah padamu yaitu hikmah Allah memberikan pelajaran padamu dengan ap a yang di turunkan itu. Dan bertaqwalah kepada Allah se rta ketahuilah bahwasanya Allah maha mengetahui segala sesuatu.(Q.S. Al-Baqarah : 231)..$^{18}$

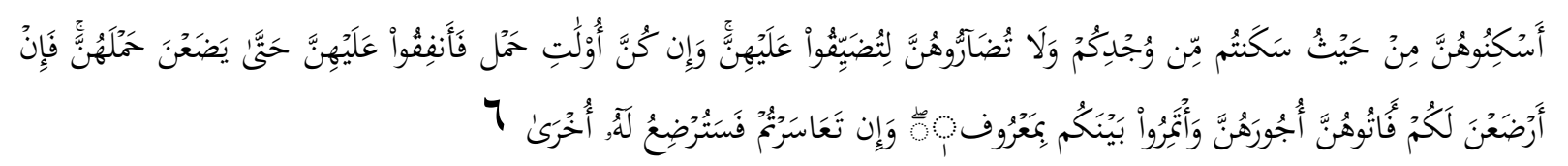

Artinya: “Tempatkanlah mereka (para isteri) di mana kamu bertempat tinggal menurut kemampuanmu dan janganlah kamu menyusahkan mereka untuk menyempitkan (hati) mereka. dan jika mereka (isteri-isteri yang sudah ditalaq) itu sedang hamil, Maka berikanlah kepada mereka nafkahnya hingga mereka bersalin, kemudian jika mereka menyusukan (anak-anak)mu untukmu Maka berikanlah kepada mereka upahnya, dan musyawarahkanlah di antara kamu (segala sesuatu) dengan baik; dan jika kamu menemui kesulitan Maka perempuan lain boleh menyusukan (anak itu) untuknya". (Q.S. at-Thalaq: 6).

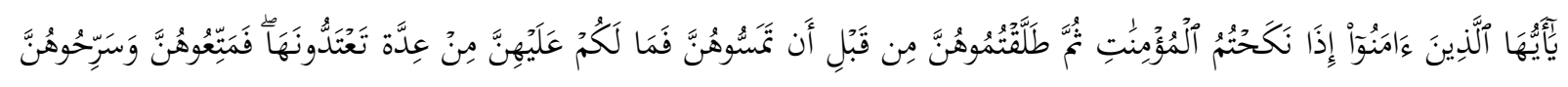

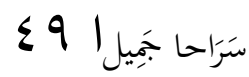

17 Ibid.

${ }^{18}$ Lihat Q.S. al-Baqarah 231. 
Artinya: "Hai orang-orang yang beriman, apabila kamu menikahi perempuan- perempuan yang beriman, kemudian kamu ceraikan mereka sebelum kamu mencampurinya Maka sekali-sekali tidak wajib atas mereka 'iddah bagimu yang kamu minta menyempurnakannya. Maka berilah mereka mut'ah dan lepaskanlah mereka itu dengan cara yang sebaik- baiknya".(Q.S. al-Ahzab: 49).

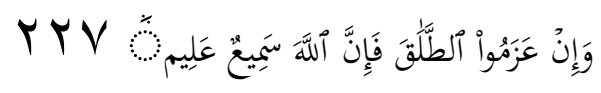

Artinya: “Dan jika mereka ber'azam (bertetap hati untuk) talak, Maka Sesungguhnya Allah Maha mendengar lagi Maha mengetahui". (Q.S. al-Baqarah: 227).

Selain itu hadis Nabi juga menjelaskan bahwa talak atau perceraian adalah perbuatan yang halal yang paling dibenci oleh Allah. ${ }^{19}$ Hadis Nabi tersebut diriwayatkan oleh Ibnu Majah no. riwayat $2008^{20}$ yang berbunyi sebagai berikut :

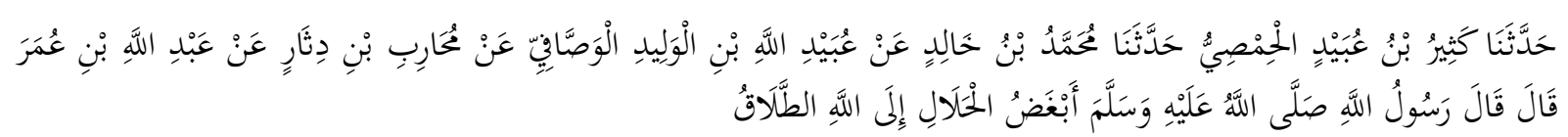

Artinya : "Dari Ibnu Umar, bahwa Rasulullah SAW bersabda : "Perbuatan halal yang sangat dibenci oleh Allah Azza wa Jalla adalah talak".

Dalam hal ini ditunjukkan pula bahwa Islam sangat berkeinginan agar kehidupan rumah tangga itu tentram dan terhindar dari keretakan, bahkan diharapkan dapat mencapai suasana pergaulan yang baik dan saling mencintai. Dan wanita yang menuntut cerai dari suaminya hanya karena menginginkan kehidupan yang menurut anggapannya lebih baik, dia berdosa dan diharamkan mencium bau surga kelak di akhirat. Karena perkawinan pada hakekatnya merupakan salah satu anugerah Ilahi yang patut untuk disyukuri.

Antara suami istri itu terjadi perjanjian yang suci yakni mitsaqan ghalidhan, perjanjian kokoh lagi sakral untuk membentuk keluarga yang bahagia kekal dan abadi (hingga maut yang memisahkan keduanya). ${ }^{21}$ Sesuai dengan firman Allah yang berbunyi:

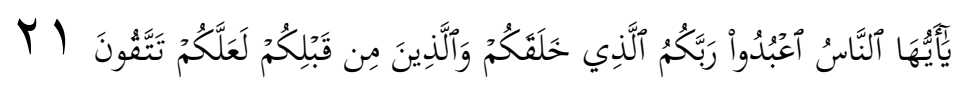

Artinya: Hai manusia, sembahlah Tuhanmu yang telah menciptakanmu dan orang-orang yang sebelummu, agar kamu bertakwa (Q.S. al-Baqarah: 21)

Oleh karena itu seyogianya hubungan suami istri itu harus langgeng, penuh kebahagiaan lahir batin, kebahagiaan rohani dan jasmani baik moral, maupun spiritual, dilandasi dengan makruf, skinah, mawaddah dan rahmah. Makruf artinya pergaulan suami istri itu, harus saling menghormati, saling menjaga rahasia masing-masing. Suami sebagai

${ }^{19}$ Ahmad Rafiq, Hukum Islam di Indonesia Jakarta : PT. Raja Grafindo Persada, 1995,hlm. 268.

${ }^{20} \mathrm{Ibnu}$ Majah, Sunan Ibnu Majah (Saudi Arabia: al-Arabiyah as-Saudiyah, 1404), jil 5, h. 441.

${ }^{21}$ Mohd. Idris Ramulyo, Hukum Perkawinan Islam: Suatu Analisis dari Undang-undang No. 1 Tanhun 1974 dan Kompilasi Hukum Islam (Jakarta: Bumi Akasar, 1996), hlm. 225. 
nakhoda dalam mengharingi kehidupan dan menyelamatkan rumah tangga hingga akhir hayatnya dalam menjaga pergaulan rumah tangga yang harmonis baik antara suami istri, maupun hubungan dengan anak-anaknya. Skinah adalah agar suasana dalam rumah tangga itu terdapat keaadaan yang aman dan tenteram, gamah ripah loh jinawe tidak terjadi perselisihan paham yang prinsipil. Semantara mawaddah dan rahmah adalah yaitu agar kehidupan rumah tangga itu selalu dijaga sehingga terjalin keutuhan dan saling cinta mencintai, saying menyayangi hingga hari tua sehingga kekal dan abadi. ${ }^{22}$

Jika dilihat berdasarkan beberapa sumber bahwa dasar hukum talak itu dibagi menjadi 4 (empat) macam yaitu:

1. Wajib

Apabila terjadi perselisihan antara suami isteri dan talak digunakan sebagai tujuan untuk menyelesaikan konflik yang terjadi antara suami isteri jika masing-masing pihak melihat bahwa talak adalah jalan satu-satunya untuk mengakhiri perselisihan. Selain terjadi syiqaq kasus ila di mana suami bersumpah tidak akan mencampuri istrinya, juga dapat mewajibkan terjadinya perceraian.

2. Sunnah

Talak disunatkan jika istri rusak moralnya, berbuat zina atau melanggar laranganlarangan agama atau meninggalkan kewajiban-kewajiban agama, seperti meninggalkan shalat, puasa, istri tidak 'afifah (menjaga diri, berlaku tidak terhormat). Hal ini dikarenakan istri yang demikian itu akan menurunkan martabat agama, mengganggu tempat tidur suami dan tidak terjamin keamanan anak yang dilahirkan.

3. Haram

Sayyid Sabiq mengemukakan bahwa talak diharamkan jika tidak ada keperluan untuk itu, karena talak yang demikian menimbulkan muhdharat, baik bagi suami maupun istri, serta melenyapkan kemaslahatan kedua suami istri itu tanpa alasan.

4. Makruh.

Berdasarkan hadits yang menetapkan bahwa talak merupakan jalan yang halal yang paling dibenci oleh Allah, yakni dibenci jika tidak ada sebab yang dibenarkan, Sedangkan Nabi tidak mengharamkannya juga karena talak dapat menghilangkan kemaslahatan yang terkandung dalam perkawinan. ${ }^{23}$

\section{DAMPAK PERCERAIAN YANG TIDAK SESUAI DENGAN PROSEDUR PERUNDANG- UNDANGAN}

Ada sebahagian rumah tangga yang selama perkawinanya rukun dan damai selama ini, kemudian setelah muncul masalah dan tidak diselesaikan dengan tuntas melalui jalur hukum yang idealnya. Sebab para pihak, baik ia pihak suami atau istri memandang sesuatu

22 Ibid., hlm. 226.

${ }^{23}$ Abdul Rahman Ghozali, Fiqh Munkahat, hlm. 217. 
masalah itu tidak perlu melibatkan institusi pengadilan dan tidak memproses melalui jalur aturan perundang-undangan yang ada. Akhirnya, dikemudian hari akan berakibat fatal dalam kehidupan masing-masing dan akan menimbulkan penyesalan yang signifikan. Namun untuk lebih jelasnya penulis akan mengulas tentang dampak dari perceraian yang tidak melalui prosedur perundang-undangan yang berlaku secara yuridis formi, adapun dampak tersebut adalah sebagai berikut ini:

1. Keabsahan perceraian.

Perkawinan yang dilaksanakan secara atauran perundang-undangan yaitu sesuai dengan yang diamanahkan oleh UU No. 1 tahun 1974 dan sah secara hukum. Kemudian setelah menjalani kehidupan rumah tangga sebagai suami istri, maka muncul permasalahan rumah tangga, sehingga terjadi perceraian, namun percraian yang dilasanakan tidak sejalan dengan aturan perundang-undangan yang ada, akan tetapi dilaksanakan sesuai dengan tradisi hukum Islam dan tradisi hukum adat. Kondisi seperti ini akan menimbulkan masalah besar nantinya dikemudian hari.

Masalah besar yang dimaksud adalah semisal jika si suami menikah lagi dengan wanita lain, di mana perkawinan tersebut dilaksanakan tanpa mengikuti aturan yang berlaku atau nikah di bawah tangan dengan istri keduanya, dan dari hasil perkawinan kedua tersebut muncul anak, maka anak tersebut akan sulit mendapatkan pengakuan hukum bahwa anak tersebut merupakan anak sah dari pernikahan di bawah tangan.

Karena pernikahannya yang kedua tersebut tidak punya kekuatan hukum atau pernikahan yang tanpa dukumen resmi negara (nikah di bawah tangan). Dengan demikian tidak bisa menerbitkan surat nikah baru, sebab belum ada bukti yang kuat sercara hukum atau secara undang-undang bahwa si sumi sudah bercerai dengan istri pertamanya dan juga belum mempunyai akte cererai.

Jika si suami dikatakan melakukan poligami, hal ini juga tidak tepat dan tidak bisa dikatakan demikian. Sebab jika suami ingin berpoligami harus memenuhi persyaratan yang ketat, Undang-undang No. 1 tahun 1974 pada pasal 3 ayat (1) menyatakan bahwa: "Pada asasnya dalam suatu perkawinan seorang pria hanya boleh mempunyai seorang isteri. Seorang wanita hanya boleh mempunyai seorang suami". Akan tetapi pada bagian yang lain dinyatakan bahwa dalam keadaan tertentu poligami dibenarkan. Hal ini ditegaskan dalam pasal selanjutnya yaitu pasal 4 yang berbunyi: (1) Dalam hal seorang suami akan beristeri lebih dari seorang, sebagaimana tersebut dalam pasal 3 ayat (2) undang-undang ini, maka ia wajib mengajukan permohonan kepada Pengadilan di daerah tempat tinggalnya. (1) Pengadilan dimaksud dalam ayat (1) pasal ini hanya memberikan izin kepada seorang suami yang akan beristeri lebih dari seorang apabila: (a) isteri tidak dapat menjalankan kewajibannya sebagai isteri; (b) isteri mendapat cacat 
badan atau penyakit yang tidak dapat disembuhkan; (c) isteri tidak dapat melahirkan keturunan. ${ }^{24}$

Selanjutnya, pada pasal 5 ayat (1) ditegaskan syarat-syarat seorang suami yang memenuhi kriteria untuk melakukan poligami, syarat tersebut berbunyi: “Untuk dapat mengajukan permohonan kepada Pengadilan, sebagaimana dimaksud dalam pasal 4 ayat (1) undang-undang ini, harus dipenuhi syarat-syarat sebagai berikut; (a) adanya persetujuan dari isteri/isteri-isteri; (b) adanya kepastian bahwa suami mampu menjamin kepeluan-keperlian hidup isteri-isteri dan anak-anak mereka. (c) adanya jaminan bahwa suami akan berlaku adil terhadap isteri-isteri dan anak-anak mereka.

Sesuai dengan alasan-alasan untuk boleh berpoligami yang disebutkan undangundang di atas, dan setelah cukup alasan maka pengadilan akan memberikan izin kepadanya untuk berpoligami. Jika dilihat dari alasan yang ada maka sangat sulit bagi seorang suami untuk menemukan alasan-alasan tersebut. Selain itu juga, untuk berpoligami seorang suami harus memenuhi beberapa syarat yang telah ditetapkan secara ketat. Dengan demikian, terkesan agak sulit untuk melakukan poligami, sebab seorang isteri pada umumnya tidak semudah itu memberikan izin atau persetujuan bagi suaminya untuk menikah lagi.

Untuk itu, lebih tepat diistilahkan dengan suami yang nikah sirri, sebab tidak punya akta nikah dan dilakukan hanya secara tradisi hukum Islam dan secara tradisi hukum adat (nikah di bawah tanga). Sementara unsur hukum positifnya dikesampingkan secara totalitas. Secara tegas dinyatakan bahwa pernikahan kedua dari suami tersebut tidak diakui secara undang-undang dan yang diakui secara yuridis adalah pernikahan yang pertama, sementara pernikahan yang pertama belum ada bukti sah secara hukum bahwa telah terjadi perceraian, sebab belum ada akta perceraian yang menyatakan bahwa pernikahan pertama telah putus secara hukum.

Secara hukum jelas akan berakibat fatal dan makin rumit dan punya masalah yang berkelanjutan jika percraiannya tidak mengikuti prosedur aturan perundang-undangan yang ada. Akhirnya jika anak lahir dari perkawinan sirri tersebut maka anak otomatis akan turut serta menanggung akibat ulah perbuatan orang tuanya. Akibat negatif yang muncul seperti, tidak bisa diterbitkan akta kelahiran anak sebab tidak mempunyai bukti pernikahan yang otentik secara hokum dari perkawinan orang tuanya. Maka secara otomatis tidak bisa mengurus kartu rumah tangga baru.

Sederetan masalah di atas, maka akan terus bermunculan deretan akibat-akibat lain dari dampak perceraian yang tidak mengikuti prosedur perceraian menurut

\footnotetext{
${ }^{24}$ Sementara Pagar mengutip pendapat Mustafa al-Siba`i menyatakan bahwa keadilan dalam berpoligami itu adalah dalam bidang materi semisal tempat tinggal yang layak, pakaian, makanan dan minuman serta hal yang bersifat kebutuhan materil isteri. Lihat Pagar, Adil Sebagai Syarat Poligami dalam Perspektif Figh dan Kompilasi Hukum Islam, Analitica Islamica, Vol 3, No. 1, 2001, hlm. 21.
} 
perundang-undangan yang ada. Pada pasal 38 disebutkan bahwa: Perkawinan dapat putus karena: (a) kematian, (b) perceraian dan (c) atas keputusan Pengadilan. Selanjutnya pada pasal 39 ayat (1) Perceraian hanya dapat dilakukan didepan Sidang Pengadilan setelah Pengadilan yang bersangkutan berusaha dan tidak berhasil mendamaikan kedua belah pihak. Ayat (2) Untuk melakukan perceraian harus ada cukup alasan, bahwa antara suami isteri itu tidak akan dapat hidup rukun sebagai suami isteri. Ayat (3) Tatacara perceraian didepan sidang Pengadilan diatur dalam peraturan perundangan tersendiri. Kemudian pada pasal 40 ayat (1) Gugatan perceraian diajukan kepada Pengadilan. Ayat (2) Tatacara mengajukan gugatan tersebut pada ayat (1) pasal ini diatur dalam peraturan perundangan tersendiri.

2. Status Perkawinan

Jika suami ingin menikah lagi dengan wanita lain, atau sebaliknya bahwa istri mau menikah dengan laki-laki lain, pada hal masalah perceraian keduanyan dengan pasangan pertamanya belum tuntas secara hukum, atau belum dituntaskan secara aturan prosedur perceraian sesuai perundang-undangan yang ada atau belum menjalani prosedur perceraian yang formil. Maka keduanya akan terhalang untuk menikah lagi dengan pasangan lain secara yuridis, sebab masih terikat dengan perkawinan yang pertama atau perkawinan sebelumnya.

Apabila ingin melaksanakan perseceraian harus sesuai dengan prosedur undangundang yang berlaku sebagaimana disebutkan pada pasal 39 ayat (1) berbunyi: Perceraian hanya dapat dilakukan didepan Sidang Pengadilan setelah Pengadilan yang bersangkutan berusaha dan tidak berhasil mendamaikan kedua belah pihak. Ayat (2) Untuk melakukan perceraian harus ada cukup alasan, bahwa antara suami isteri itu tidak akan dapat hidup rukun sebagai suami isteri.

Perceraian yang dinyatakan sah secara yuridis, jika telah mempunyai akta perceraian dan telah menjalani prosedur perceraian sesuai dengan apa yang telah diatur. Secara hukum kedua belah pihak akan terhalang untuk melakukan perkawinan yang kedua dengan pasangan yang berbeda. Di dalam UU No. 1 tahun 1974 telah diatur bahwa pada pasal 15 yang berbunyi: Barang siapa karena perkawinan dirinya masih terikat dengan salah satu dari kedua belah pihak dan atas dasar masih adanya perkawinan, dapat mencegah perkawinan yang baru, dengan tidak mengurangi ketentuan Pasal 3 ayat (2) dan Pasal 4 Undang-undang ini. Pasal 16 ayat (1) Pejabat yang ditunjuk berkewajiban mencegah berlangsungnya perkawinan apabila ketentuan-ketentuan dalam Pasal 7 ayat (1), Pasal 8, Pasal 9, Pasal 10 dan Pasal 12 Undang-undang ini tidak dipenuhi. Ayat (2) Mengenai Pejabat yang ditunjuk sebagaimana tersebut pada ayat (1) pasal ini diatur lebih lanjut dalam peraturan perundang-undangan.

Pada pasal 17 ayat (1) Pencegahan perkawinan diajukan kepada Pengadilan dalam daerah hukum dimana perkawinan akan dilangsungkan dengan memberitahukan juga 
kepada pegawai pencatat perkawinan. Ayat (2) Kepada calon-calon mempelai diberi tahukan mengenai permohonan pencegahan perkawinan dimaksud dalam ayat (1) pasal ini oleh pegawai pencatat perkawinan. Pada pasal 18 berbunyi: Pencegahan perkawinan dapat dicabut dengan putusan Pengadilan atau dengan menarik kembali permohonan pencegahan pada Pengadilan oleh yang mencegah. Itulah sederetan aturan bagi mereka yang ingin melangsungkan perkawinan secara undang-undang.

Melihat aturan yang ada di atas, tidak mungkin perkawinan yang kedua akan dilaksanakan secara hukum sesuai dengan aturan yang ada dalam UU No. tahun 1974 dan Peraturan Pemerintah (PP) No. 9 tahun 1975 tentang pelaksanaan UU No. 1 tahun 1974. Dengan mengikuti prosedur perkawinan yang disebutkan pada pasal-pasal di atas, maka jelas pasangan yang akan menikah untuk yang kedua kalinya dan belum ada putusan perceraian tentang perkawinan sebelumnya secara hukum, akan ketahuan bahwa pernikahan yang pertama belum tuntas dan belum diproses perceraiannnya secara undang-undang yang berlaku.

3. Nafkah

Secara filosofis memperoleh keturunan yang sah adalah tujuan pokok dari perkawinan itu sendiri. Memperoleh anak dalam perkawinan bagi penghidupan manusia mengandung dua segi kepentigan, yaitu kepentingan untuk diri pribadi dan kepentingan yang bersifat umum (universal). Setiap orang yang melaksanakan perkawinan tentu mempunyai keinginan untuk memperoleh anak atau keturunan. ${ }^{25}$ Secara yuridis, kedudukan anak dalam perkawinan diatur dalam pasal 42 UU No. 1 tahun 1974 yang memuat ketentuan definitif bahwa anak yang sah adalah anak yang dilahirkan dalam atau sebagai akibat perkawinan yang sah. Kemudian, menurut ketentuan limitatif dalam pasal 43 ayat (1) UU No. 1 tahun 1974, anak yang dilahirkan di luar perkawinan hanya mempunyai hubungan perdata dengan ibinya dan keluarga ibunya. ${ }^{26}$

Hal ini menunjukkan bahwa jika terjadi masalah percerain antara suami istri, maka yang menjadi sasaran utama adalah anak-anak yang lahir akibat dari perkawinan yang sah di antara suami dan istri. Pada hal dalam peraturan perundang-undangan diatur pada pasal 41 dijelaskan bahwa: Akibat putusnya perkawinan karena perceraian ialah: (a) Baik ibu atau bapak tetap berkewajiban memelihara dan mendidik anakanaknya, semata-mata berdasarkan kepentingan anak-anak, bilamana ada perselisihan mengenai penguasaan anak-anak pengadilan member keputusannya. (b) Bapak yang bertanggung jawab atas semua biaya pemeliharaan dan pendidikan yang diperlukan anak itu bilamana bapak dalam kenyataan tidak dapat memenuhi kewajiban tersebut. Pengadilan dapat menentukan bahwa ibu ikut memikul biaya tersebut. (c) pengadilan

${ }^{25}$ Soemiyati, Hukum Perkawinan Islam dan Undang-Undang Perkawinan (UU No. 1 Tahun 1974 tentang perkawinan), (Yogyakarta: Liberty, 1982), hlm. 13-14.

${ }^{26}$ Muhammad Syaifuddin dkk, Hukum Perceraian, hlm. 355. 
dapat mewajibkan kepada bekas suami untuk memberikan biaya penghidupan dan/atau menentukan sesuatu kewajiban bagi bekas intrinya.

Pada kenyataannya jika terjadi perceraian antara suami dan istri, kabanyakan suami akan melalaikan kewajibannya untuk memberikan nafkah kepada anaknya sebagai kewajiban mutlak untuk dinafkahi. Dengan demikian, yang jadi korban utama adalah anak-anak dari hasil perkawinan. Padahal aturan perundang-undangan telah mengatur secara tegas, selain itu hukum islampun tetap mewajibkan hal yang sama seperti apa yang telah ditetapkan oleh undang-undang No. 1 tahun 1974.

Permasalahan yang lebih rumit lagi jika si suami menikah dengan wanita lain dengan perkawinan secara tradisi hukum Islam dan tradisi hukum adat, kemudian dari perkawinan tersebut melahirkan keturunan. Sementara kasus perceraiannya dengan istri pertama belum tuntas secara yuridis. Kondisi ini akan mengakibatkan masalah yang sangat kompleks, semisal apabila istri kedua dari perkawinan yang kedua (yang nikah secara tradisi hukum Islam dan tradisi hukum adat) terjadi lagi masalah perceraian dengan istri sirrinya, maka istri sirri tidak bisa menuntut tanggungjawab suami sirrinya melalui jalur hukum, karena perkawinan yang dilakukan keabsahannya hanya sah secara tradisi hukum Islam dan tradisi semata. Sementara menurut UU No. 1 tahun 1974 tidak diakui secara yuridis formil.

Sedangkan anak yang lahir dari perkawinan sirri tersebut di atas, jelas bukan anak dari suami sirrinya secara undang-undang, anak yang lahir tersebut hanya mempunyai hubungan perdata dengan pihak ibunya saja, sebagaimana diatur dalam Pasal 42 UU No. 1 tahun 1974 yang berbunyi: Anak yang sah adalah anak yang dilahirkan dalam atau sebagai akibat perkawinan yang sah. Pada pasal 43 ayat (1) Anak yang dilahirkan diluar perkawinan hanya mempunyai hubungan perdata dengan ibunya dan keluarga ibunya. Dan ayat (2) Kedudukan anak tersebut ayat (1) di atas selanjutnya akan diatur dalam Peraturan Pemerintah.

Sejalan dengan aturan perundang-undangan di atas, maka jelas status anak yang lahir di luar perkawinan tidak diakui oleh undang-undang, maka konsekuensinya adalah anak yang lahir dari perkawinan sirri hanya mempunyai hubungan perdata dengan ibunya dan keluarga ibunya saja. Jadi istri sirri tidak berhak secara hukum atau secara undang-undang menuntut nafkah atau kebutuhan anak tersebut agar dipenuhi suami sirrinya, dan suami sirri akan berdalih bahwa ia tidak mau bertnggung jawab atas semua kebutuhan anak tersebut, sebab anak itu lahir dari status perkawinan yang tidak sesuai dengan aturan perundang-undangan yang ada yaitu UU No. 1 tahun 1974.

Sangat rentan pihak laki-laki untuk melepaskan kewajibannya jika suatu perkawinan begitu juga dengan perceraian jika tidak dijalankan sesuai dengan aturan yang berlaku menurut perundang-undangan yang ada. Tidak sedikit permasalahan rumah tangga berkhir dengan perceraian di Pengadilan Agama disebabkan suami tidak 
menjalankan fungsinya sebagai kepala rumah tangga, dengan kata lain tidak menafkahi anak dan istrinya, padahal perkawinan yang dilaksanakan selama ini sesuai dengan apa yang ada dalam UU No. 1 tahun 1974.

\section{Status Harta Bersama}

Harta bersama adalah harta kekayaan yang diperoleh selama perkawinan di luar hadiah atau warisan. Dengan kata lain, harta yang didapat atas usaha mereka berdua, atau sendiri-sendiri selama masa ikatan perkawinan. ${ }^{27}$ Dalam istilah figh mu amalah dapat dikategorikan sebagai syirkah atau join antara suami istri. Secara konvensional, beban ekonomi keluarga adalah hasil pencaharian suami, sedangkan istri sebagai ibu rumah tangga bertindak sebagai manajer yang mengatur manajemen ekonomi rumah tangganya. Untuk pengertian yang lebih luas dan disesuaikan dengan tuntutan perkembangan, istri juga dapat melakukan pekerjaan yang dapat mendatangkan kekayaan. Jika yang pertama, digolongkan ke dalam syirkah al-abdan, modal dari suami, istri andil jasa tenaganya. Yang kedua, di mana masing-masing mendatangkan modal, dikelola bersama, disebut dengan syirkah inan. $^{28}$

Jono menyimpulkan pendapatnya tentang harta bersama yaitu: bahwa harta bersama dalam perkawinan merupakan suatu harta bersama yang terikat (hak milik bersama yang terikat), yang mana seseorang suami ataupun istri tidak dapat berbuat bebas atas harta bersama secara mandiri, tetapi harus berdasarkan persetujuan kedua belah pihak. ${ }^{29}$

Menurut Mohd. Idris Ramulyo bahwa harta bersama tersebut muncul tidak perlu diiringi dengan syirkah, sebab perkawinan dengan ijab dan qabul serta memenuhi persayaratan lain-lainnya seperti adanya wali, saksi, mahar, walimah dan 'iklanun nikah sudah dapat dianggap adanya syirkah antara suami istri. Selanjutnya ia berkomentar, bilamana istri dari seorang suami hamil, kemudian melahirkan anak, sedangkan suami tidak turut mengandung anak yang dikandung istrinya itu dan tidak pula turut serta menderita melahirkan anak tetapi anak tersebut tidak dapat ikatakan anak si istri saja tetulah tidak, sebab anak itu adalah anak dari hasil perkawinan antara suami istri, bahkan lazimnya lebih ditonjolkan nama suami atau ayah dibelakang nama anak. Demikian pula halnya bilamana suami saja yang bekerja, berusaha dan mendapat harta, tidak dapat dikatakan bahwa harta iti hanya harta suami saja, tentulah tidak, melainkan telah menjadi harta bersama suami istri. Apabila terjadi putus hubungan perkawinan, baik karena cerai atau talak atas permohonan suami, atau atas gugatan pihak istri, maka harta bersama

\footnotetext{
${ }^{27}$ Sajuti Thalib, Hukum Kekeluargaan Indonesia, cet. V (Jakarta: UI Press, 1986), hlm. 89. Lihat juga Ahmad Rofiq, Hukum Perdata Islam di Indonesia, hlm. 161.

${ }^{28}$ Ahmad Rofiq. Hukum Islam di Indonesia, hlm. 161.

${ }^{29}$ Jono, Hukum Kepailitan, (Jakarta: Sinar Grafika, 2008), hlm. 37.
} 
yang diperoleh selama perkawinan itu harus dibagi antara suami istri, menurut perimbangan yang sama. ${ }^{30}$

5. Status Harta Gono-gini dan Harta Warisan

Masalah harta warisan pada prinsipnya telah diatur secara jelas dalam Kompilasi Hukum Islam (KHI) bagian masing-masing suami istri yakni pada pasal 96 (1) Apabila terjadi cerai mati, maka separuh harta bersama menjadi hak pasangan yang hidup lebih lama, (2) Pembangian harta bersama bagi seorang suami atau isteri yang isteri atau suaminya hutang harus ditangguhkan sampai adanya kepastian matinya yang hakiki atau matinya secara hukum atas dasar putusan Pengadilan Agama. Kemudian pasal 97 Janda atau duda cerai masing-masing berhak seperdua dari harta bersama sepanjang tidak ditentukan lain dalam perjanjian perkawinan.

Namun yang menjadi masalah utama adalah, ketika terjadi masalah rumah tangga yang pada akhirnya terjadi perceraian dan prosedur perceraiannya tidak sejalan dengan apa yang diatur dalam UU No. 1 tahun 1975, akan tetapi perceraiannya dengan menerapkana sesuai dengan tradisi hukum Islam dan tradisi hukum adat setempat tidak secara hukum formil. Pada posisi seperti ini jika di antara suami istri salah satunya tibatiba meninggal dunia, sementara secara tradisi hukum yang ada telah cerai, dan secara hukum positif atau UU No. 1 tahun 1974 belum ada perceraian sebab belum ada proses yang diajukan sesuai aturan hukum positif.

Situasi di atas akan menjadi dampak buruk bagi keluarga dan anak-anaknya, apalagi masyarakat setempat lebih mementingkan tradisi hukum setempat. Apabila merujuk kepada tradisi hukum Islam maka setelah bercerai maka harta akan dibagi dua, secara otomatis mantan istri tidak mendapatkan harta warisan dari mantan suaminya yang meninggal dunia setelah terjadinya perceraian secara tradisi hukum setempat.

Akan tetapi jika merujuk pada UU No. 1 tahun 1974 maka belum ada timbul perceraian secara hukum. Sebab para pihak sebelumnya telah megabaikan prosedur perceraian yang telah ditetapkan dalam aturan perundang-undangan yang ada. Sebab jika telah terjadi perceraian antara suami dan istri, baik secara tradisi hukum maupun secara UU No. 1 tahun 1974 jelas hubungan kekeluargaan antara pihak keluarga suami dan pihak istri pasti ada ketidak harmonisan. Sementara penerapan hukum waris yang akan dilaksanakan bisa saja kedua pihak keluarga yang telah bercerai berbeda dalam memilih hukum yang dijalankan.

Pihak-pihak yang merasa teruntungkan dengan tradisi hukum yang ada pasti berkeinginan dengan cara pembagian harta warisannya secara tradisi hukum setempat. Sedangkan pihak yang diuntungkan dengan penerapan pembagian hukum waris yang

\footnotetext{
${ }_{30}$ Mohd. Idris Ramulyo, Hukum Perkawinan Islam: Suatu Analisis Dari Undang-undang No. 1 Tahun 1974 Dan Kompilasi Hukum Islam (Jakarta: Bumi Aksara, 1996), hlm. 232.
} 
ada dalam Kompilasi Hukum Islam dan sesuai dengan UU No. 1 tahun 1974 sedah tentu tetap mengiginkan diterapkannya sesuai aturan perundang-undangan yang berlaku secara yuridis.

\section{PENUTUP}

Aturan hukum merupakan suatu hal yang seharusnya untuk ditaati dalam menjalani kehidupan, agar semua perbutan yang dilakukan sejalan dengan norma hukum yang ada. pelanggaran terhadap norma hukum yang ada akan mengakibatkan timbulnya tindakan melawan hukum yang akhirnya berkaibat fatal baik terhadap diri sendiri juga terhadap orang lain nantinya. Bukankah hukum sebagai panglima dalam kehidupan bernegara, untuk itu taatilah hukum yang ada sepanjang hukum itu bisa memberikan rasa keadilan, kenyamanan dan memenuhi rasa keadilan untuk semua warga Negara.

\section{DAFTAR PUSTAKA}

Abdul Djamali, Hukum Islam, Bandung: Mandar Maju, 1997. 
FITRAH Vol.01 No. 1 Januari-Juni 2015

Abdul Rahman Ghozali, Fiqh Munakahat, Jakarta: Prenada Media, 2003.

Abdurrahman al-jaziri, Kitab al-Figh `ala Mazahib al-Arba`ah, Juz IV, Kairo: Dar al-Fikr, t.t.

Abu Yahya Zakariya al-Anshary, Fath al-Wahhab, Singapura: Sulaiman Mar’iy, t.t.

Ahmad Rafiq, Hukum Islam di Indonesia Jakarta : PT. Raja Grafindo Persada, 1995.

Fuad Said, Perceraian Menurut Hukum Islam, Jakarta: Pustaka al-Husna, 1994.

H. Mahmud Yunus, Kamus Ara Indonesia, Yayasan Penyelenggara Penterjemah/Penafsiran Al-Qur'an, Jakarta, 1973.

H.S.A. Al-Hamdani, Risalah Nikah, Jakarta: Pustaka Amani, 2002.

Ibnu Majah, Sunan Ibnu Majah, Saudi Arabia: al-Arabiyah as-Saudiyah, 1404.

Imam Taqi al-Din Abu Bakr ibn Muhammad Al-Hussaini, Kifayah Al Akhyar, Beirut: Dar alKutub al-Ilmiah, t.t.

Jono, Hukum Kepailitan, Jakarta: Sinar Grafika, 2008.

Mohd. Idris Ramulyo, Hukum Perkawinan Islam: Suatu Analisis dari Undang-undang No. 1 Tanhun 1974 dan Kompilasi Hukum Islam, Jakarta: Bumi Akasar, 1996.

Muhammad Syaifuddin, Sri Turatmiyah dan Annalisa Yahana, Hukum Perceraian, Jakarta Timur: Sinar Grafika, 2013.

Pagar, Adil Sebagai Syarat Poligami dalam Perspektif Figh dan Kompilasi Hukum Islam, Analitica Islamica, Vol 3, No. 1, 2001, hlm. 21.

Sajuti Thalib, Hukum Kekeluargaan Indonesia, cet. V, Jakarta: UI Press, 1986.

Sayyid Sabiq, Fiqh al-Sunnah, Bandung: PT. Al-Ma`arif, 1994.

Soemiyati, Hukum Perkawinan Islam dan Undang-Undang Perkawinan (UU No. 1 Tahun 1974 tentang perkawinan), Yogyakarta: Liberty, 1982.

Soerojo Wignjodipoero, Pengantar dan Asas-Asas Hukum Adat, Jakarta: Haji Masagung, 2004.

Subekti, Pokok-Pokok Hukum Perdata, Jakarta: PT. Intermasa, 1994.

Tim Penyusun Kamus Pusat Pembinaan dan Pengembangan Bahasa, Kamus Besar Bahasa Indonesia Edisi Kedua, Jakarta: Balai Pustaka, 1997.

Zahry Hamid, Pokok-Pokok Hukum Perkawinan Islam dan Undang-Undang Perkawinan di Indonesia, Yogyakarta: Bina Cipta, 1978. 